\title{
ANALISIS FAKTOR YANG MEMPENGARUHI TURNOVER INTENTION DI PANCA SUMBER DIESEL GROUP PEKANBARU
}

\section{ANALYSIS FACTORS THAT AFFECTING TURNOVER INTENTION IN PANCA SUMBER DIESEL GROUP PEKANBARU}

\author{
Zulfadli Hamzah \\ Universitas Islam Riau \\ zulfadlihamzah@gmail.com
}

Submit, 11-03-2019 Accepted,02-04-2019 Publish,03-04-2019

\begin{abstract}
Managing a company is not something that is easy, there are many obstacles that might be faced in creating a quality and competent company, especially managing people within the company. This study aims to determine the effect of leadership and motivation on turnover intention at the Panca Source Diesel Group. Analysis was carried out on 32 respondents, this study was taken by census method and data was collected through questionnaires. The data analysis technique used is multiple linear regression through $T$ test statistics and test models ( $F$ and Coefficient of reflection). The results showed that the overall leadership and motivation variables partially or simultaneously had an effect on turnover intention.
\end{abstract}

Keywords: Leadership, Motivation, Turnover Intention

\begin{abstract}
ABSTRAK
Mengelola perusahaan bukanlah sesuatu hal yang mudah, Banyak hambatan yang mungkin akan dihadapi dalam mewujudkan perusahaan yang berkualitas dan berkompeten, terutama mengelola manusia di dalam perusahaan. Penelitian ini bertujuan untuk mengetahui pengaruh kepemimpinan dan motivasi terhadap turnover intention di Panca Source Diesel Group. Analisis dilakukan pada 32 responden, penelitian ini diambil dengan metode sensus dan data dikumpulkan melalui kuesioner. Teknik analisis data yang digunakan adalah regresi linier berganda melalui statistik uji $\mathrm{T}$ dan model uji (F dan Koef.determinan). Hasil penelitian menunjukkan bahwa keseluruhan variable kepemimpinan dan motivasi secara parsial maupun simultan berpengaruh terhadap turnover intention.
\end{abstract}

Kata Kunci: Kepemimpinan, Motivasi, Turnover Intention

\section{PENDAHULUAN}

Sumber daya manusia (SDM) berperan sangat penting sebagai unsur utama sebuah perusahaan dibandingkan unsur lainnya seperti modal dan teknologi, sebab manusia itu sendiri yang mengendalikan jalannya sebuah perusahaan. Secanggih apapun sumber daya yang dimiliki perusahaan akan terasa nihil jika tidak dilengkapi dengan kemampuan yang berkualitas dan berkompeten dari sumber daya manusia yang dimilikinya. Kemampuan yang berkualitas dan berkompeten dari sumber daya manusia itulah yang akan 
menentukan kemajuan sebuah perusahaan di masa yang akan datang.

Mengelola perusahaan bukanlah sesuatu hal yang mudah, Banyak hambatan yang mungkin akan dihadapi dalam mewujudkan perusahaan yang berkualitas dan berkompeten, terutama mengelola manusia di dalam perusahaan. Keberadaan manajamen sumber daya manusia dalam suatu perusahaan bertujuan untuk meningkatkan kontribusi karyawan terhadap organisasi dalam rangka mencapai tujuan perusahaan. Turnover intention merupakan niat karyawan untuk meninggalkan organisasi sebagai sadar dan hasrat disengaja dari karyawan untuk meninggalkan organisasi. Turnover intention yang terjadi merugikan perusahaan baik dari segi biaya, sumber daya, maupun motivasi karyawan. turnover intention yang terjadi berarti perusahaan kehilangan sejumlah tenaga kerja. Kehilangan ini harus diganti dengan karyawan yang baru. Perusahaan harus mengeluarkan biaya mulai dari perekrutan hingga mendapatkan pekerja yang siap pakai.

Keluarnya karyawan berarti ada posisi tertentu yang lowong yang segera diisi. Selama masa lowong maka tenaga kerja yang ada kadang tidak sesuai dengan tugas yang ada sehingga terbengkalai. Karyawan yang tinggal akan terpengaruh motivasi. Karyawan yang sebelumnya tidak berusaha mencari pekerjaan baru akan mulai mencari lowongan kerja, kemudian akan melakukan turnover intention. Hal ini jelas membawa kerugian.Berikut ini ada tabel Turnover Intention karyawan Panca Sumber Diesel Group :

Tabel 1. Turnover Intention Karyawan Panca Sumber Diesel Group

\begin{tabular}{ccccccc} 
Nama & \multicolumn{2}{c}{2013} & \multicolumn{2}{c}{2014} & \multicolumn{2}{c}{2015} \\
\cline { 2 - 6 } Pekerjaan & M & K & M & K & M & K \\
\hline
\end{tabular}

\begin{tabular}{ccccccc}
\hline Sales & 5 & 4 & 3 & 3 & 6 & 4 \\
\hline Administrasi & 3 & 2 & 2 & 1 & 2 & 2 \\
\hline Supervisor & 1 & 0 & 1 & 0 & 1 & 1 \\
\hline Kasir & 2 & 1 & 0 & 0 & 1 & 1 \\
\hline
\end{tabular}

Sumber : Panca Sumber Diesel Group (2016)

Dari tabel di atas pada bagian sales lebih sering terjadi Turnover intention dari pada bagian administrasi, supervisor dan kasir. tingkat turnover intention yang tinggi menimbulkan kerugian baik dari segi biaya maupun waktu dan akibatnya harus melakukan perekrutan kembali, yang berakibat memberikan dampak yang sangat negative bagi perusahaan. Kondisi ini pun mempengaruhi kepada karyawan lainnya karena pekerjaan yang seharusnya dikerjakan, menjadi kacau dikarenakan kurangnya karyawan, dan ini memberikan dampak negatif bagi perkembangan perusahaan maupun proses berjalannya perusahaan.

Masalah tingkat kehadiran yang berfluktuasi yang dijelaskan pada tabel di atas kemungkinan terjadi karena kurang adanya motivasi dari pihak perusahaan, seperti karyawan mengharapkan akan mendapatkan pujian dari pimpinan ketika menyelesaikan tugas tepat waktu, namun ternyata harapan karyawan tersebut tidak tercapai, perusahaan/pemimpin tidak memberikan respon yang baik kepada karyawannya.

Manajemen sumber daya manusia adalah suatu pengelolaan dan pendayagunaan sumber daya yang ada pada individu (Mangkunegara, 2007). Hasibuan (2012) mendefinisikan manajemen sumber daya manusia adalah ilmu dan seni yang mengatur hubungan dan peranan tenaga kerja agar efektif dan efisien membantu terwujudnya tujuan perusahaan, karyawan dan masyarakat. Sedangkan menurut Mathis dan Jackson (2006) SDM adalah rancangan sistem-sistem 
formal dalam sebuah organisasi untuk memastikan penggunaan bakat manusia secara efektif dan efisien guna mencapai tujuan organisasi.

Beberapa definisi di atas dapat disimpulkan bahwa manajemen sumber daya manusia adalah suatu proses perencanaan, pengorganisasian, pengarahan dan pengendalian diri dari pengadaan, pengembangan, kompensasi, pengintergrasian dan pemeliharaan untuk mencapai tujuan yang telah ditetapkan.

Kepemimpinan adalah proses mempengaruhi atau memberi contoh kepada pengikut-pengikutnya lewat proses komunikasi dalam upaya mencapai tujuan organisasi (Rivai 2009). Menurut Heidjrachman dan Husna (2011), gaya kepemimpinan adalah berbagai pola tingkah laku yang dirancang untuk mengintegrasiakan tujuan organisasi dengan tujuan individu untuk mencapai tujuan tertentu.

Berdasarkan pengertianpengertian di atas dapat disimpulkan bahwa gaya kepemimpinan adalah kemampuan seseorang pemimpin dalam mengarahkan, mempengaruhi, mendorong dan mengendalikan orang bawahan untuk bisa melakukan suatu pekerjaan atas kesadarannya dan sukarela dalam mencapai suatu tujuan tertentu.

Motivasi adalah serangkaian sikap dan nilai-nilai yang mempengaruhi individu untuk mencapai hal yang spesifik sesuai dengan tujuan individu. Motivasi mengacu pada suatu proses mempengaruhi pilihan-pilihan individu terhadap bermacam-macam bentuk kegiatan yang dikehendaki, Sedangkan menurut Samsudin (2010), menyatakan bahwa motivasi adalah proses mempengaruhi atau mendorong dari luar terhadap sesorang atau kelompok kerja agar mereka mau melaksanakan sesuatu yang telah ditetapkan

Berdasarkan pengertianpengertian diatas dapat disimpulkan bahwa motivasi merupakan kegiatan yang mendorong perilkau manusia untuk mencapai suatu tujuan dan setiap dorongan atau motivasi yang timbul pada individu masing-masing.

Menurut Mathis dan Jackson (2006), perputaran adalah proses dimana karyawan meninggalkan organisasi dan harus digantikan. Sedangkan menurut Rivai (2009) turnover intention merupakan keinginan karyawan untuk berhenti kerja dari perusahaan secara sukarela atau pindah dari satu tempat ke tempat kerja yang lain menurut pilihannya sendiri.

Robbins (2006) mendefinisikan turnover intention sebagai pemberhentian pegawai yang bersifat permanent dari perusahaan baik yang dilakukan oleh pegawai sendiri (secara sukarela) maupun yang dilakukan oleh perusahaan.

Menurut Rodly (2012), turnover intention yaitu niat karyawan untuk meninggalkan organisasi sebagai sadar dan hasrat disengaja dari karyawan untuk meninggalkan organisasi anggota-anggota kelompok dengan mempergunakan cara atau gaya tertentu.

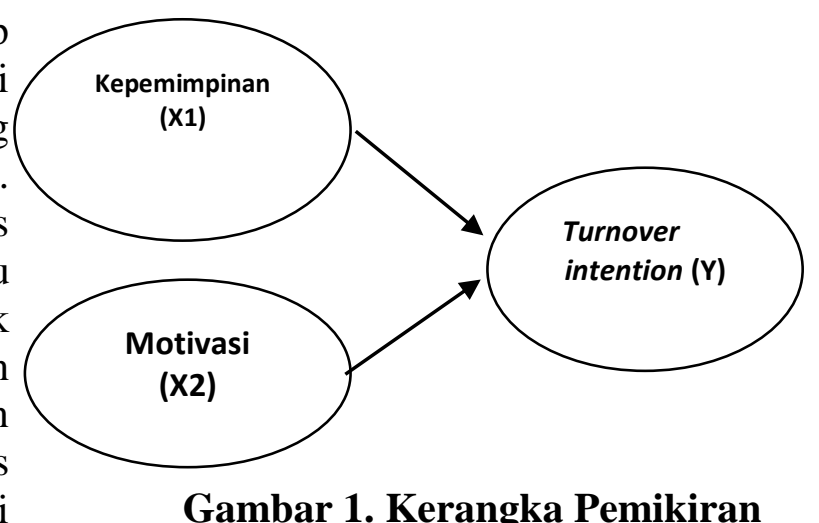

Gambar 1. Kerangka Pemikiran 
Dengan kerangka pemikiran yang ada maka dapat dirumuskan hipotesi sebagai berikut :

H1 : kepemimpinan memiliki pengaruh terhadap turnover intention di Panca Sumber Diesel Group

$\mathrm{H} 2$ : Motivasi memiliki pengaruh terhadap turnover intention di Panca Sumber Diesel Group

\section{METODE PENELITIAN}

Populasi yang ada dalam penelitian ini adalah seluruh karyawan Panca Sumber Diesel Group yang berjumlah sebanyak 32 orang. Oleh karena penelitian ini menggunakan metode sensus maka keseluruhan populasi di Panca Sumber Diesel Group di jadikan sebagai responden penelitian yaitu sebanyak 32 orang karyawan

\section{Variabel Definisi Operasional}

Dalam penelitian ini digunakan 2 variabel yaitu : (1) Variabel bebas (independent variable) Variabel bebas $\mathrm{X}$ merupakan variabel yang mempengaruhi variabel lain, dalam penelitian ini variabel bebas yang diteliti terdiri dari : Kepemimpinan dan Motivasi (2) Variabel terikat (dependent variable) Variabel terikat Y merupakan variabel yang dipengaruhi oleh variabel lain dalam penelitian ini variabel yang dipengaruhi oleh variabel lain yaitu Turnover intention

\section{Teknik Analisis Data}

\section{Analisis Deskriptif}

Analisis deskriptif dalam penelitian ini merupakan uraian atau penjelasan dari hasil data primer berupa kuesioner yang telah diisi oleh responden penelitian, Analisis deskriptif digunakan untuk mengetahui dan mendeskripsikan variabel bebas dan variabel terikat.

\section{Uji F (Uji Simultan)}

Uji Statistik F pada dasarnya menunjukkan apakah semua variabel independen yang dimaksud dalam penelitian mempunyai pengaruh secara simultan terhadap variabel dependen. Dasar pengambilan keputusan Uji F (uji Simultan): apabila $F_{\text {tabel }}>F_{\text {hitung, maka }}$ maka dinyatakan model layak digunakan. Apabila $\mathrm{F}$ tabel $<\mathrm{F}$ hitung, maka dinyatakan model tidak layak digunakan.

\section{Koefisien Determinasi $\left(\mathbf{R}^{2}\right)$}

Koefisien determinasi $\left(\mathrm{R}^{2}\right)$ digunakan untuk menjelaskan proporsi variabel dependen (bebas) yang mampu dijelaskan oleh variasi variabel independennya (terikat). Nilai koefisien determinasi adalah $0<2<1$. Nilai $R^{2}$ berkisar antara $0-1 \%$ dan jika nilainya mendekati 1 maka semakin baik. Semakin besar koefisien determinasinya, maka semakin baik variabel independen dalam menerangkan variabel dependen.

\section{Analisis Regresi Linier Berganda}

Model yang akan dipergunakan dalam penelitian ini adalah analisis regresi linier berganda (Multiple Regression) dengan bantuan program SPSS (Statistical Product and Service Solutions), model regresi yang digunakan dinyatakan dalam persamaan ini $Y=a+\beta_{1} X_{1}+\beta_{2} X_{2}+e$.

\section{Uji t (Uji Parsial)}

Menurut Ghozali,2011, pengujian ini bertujuan untuk mengetahui apakah dalam model regresi linier, variabel independen secara parsial mempunyai pengaruh terhadap variabel dependen. Pada uji $t$, nilai $t$ hitung akan dibandingkan dengan nilai $\mathrm{t}$ tabel masing-masing variabel : (1) Apabila t tabel $>\mathrm{t}$ hitung maka Ho diterima dan $\mathrm{Ha}$ ditolak pada $\alpha=0,05$ (2) Apabila t tabel $<\mathrm{t}$ hitung, maka Ho ditolak dan $\mathrm{Ha}$ diterima pada $\alpha=0,05$

\section{HASIL DAN PEMBAHASAN Analisis Deskriptif}

Analisis deskriptif adalah suatu metode analisis dimana data-data yang ada dikumpulkan atau dikelompokkan 
kemudian data-data tersebut dianalisis dan diinterprestasikan secara objektif. Hasil analisis statistik deskriptif ini disarikan dalam tabel berikut:

Tabel 2 Analisis Dekriptif

\begin{tabular}{|c|c|}
\hline $\begin{array}{l}\text { Variabel } \\
\text { Indenpenden/Variabel } \\
\text { Dependen }\end{array}$ & $\begin{array}{l}\text { Total Rata-rata } \\
\text { Skor }\end{array}$ \\
\hline Kepemimpinan & 3.78 \\
\hline Motivasi & 3.90 \\
\hline Turnover Intention & 3.79 \\
\hline
\end{tabular}

Sumber : hasil penelitian (diolah) 2016

Berdasarkan hasil penelitian di atas dapat dilihat bahwa skor rata-rata yang ditunjukkan dari variabel kepemimpinan adalah sebesar 3.78 . dapat diartikan bahwa variable kepemimpinan dinilai baik oleh karyawan. hal ini mengindikasikan bahwa indikator kepemimpinan yang diterapkan sudah dianggap baik oleh karyawan.

Kemudian untuk variabel yang kedua yaitu motivasi dengan nilai sebesar 3.90, dimana skor motivasi lebih tinggi dari pada variabel kepemimpinan dan hal ini juga mengindikasikan bahwa variabel motivasi dianggap baik oleh karyawan di perusahaan yang berdampak pada Turnover Intention

Uji F

\begin{tabular}{lcccr}
\multicolumn{5}{c}{ Tabel 3. Uji Signifikansi secara } \\
\cline { 2 - 6 } \\
\cline { 2 - 6 } Simultan
\end{tabular}

Sumber : Hasil Penelitian (diolah) 2016

Dari hasil pengujian secara simultan diperoleh hasil $\mathrm{F}_{\text {hitung }}$ adalah 15.204 sedangkan nilai $F_{\text {tabel }}$ adalah 3.295, sehingga $\mathrm{H}_{0}$ ditolak dan $\mathrm{H}_{1}$ diterima yang berarti secara bersamasama kepemimpinan dan motivasi secara simultan berpengaruh secara signifikan terhadap turnover intention.

Koefisien Determinasi $\left(\mathbf{R}^{2}\right)$

Tabel 4. Koefisien Determinasi

\begin{tabular}{lcccc}
\hline Model & $\mathrm{R}$ & $\begin{array}{c}\mathrm{R} \\
\text { Square }\end{array}$ & $\begin{array}{c}\text { Adjusted R } \\
\text { Square }\end{array}$ & $\begin{array}{c}\text { Std. Error } \\
\text { of the } \\
\text { Estimate }\end{array}$ \\
\hline 1 & $0.715^{\mathrm{a}}$ & 0.512 & 0.478 & 0.37296 \\
\hline \multicolumn{3}{l}{ Sumber : Hasil Penelitian (diolah) 2016}
\end{tabular}

Dari hasil pengujian yang telah dilakukan, nilai koefisien determinasi (RSquare) sebesar 0.512. Dengan demikian dapat disimpulkan bahwa perataan laba mampu dijelaskan oleh variabel independen (Kepemimpinan dan Motivasi) sebesar 51.2\%. Sedangkan selebihnya sebesar $48.8 \%$ dijelaskan oleh variabel lain yang tidak diteliti dalam penelitian ini.

\section{Analisis Regresi Linier Berganda}

Adapun model persamaan yang digunakan dalam penelitian ini adalah sebagai berikut :

\section{Tabel 5. Regresi Linier Berganda}

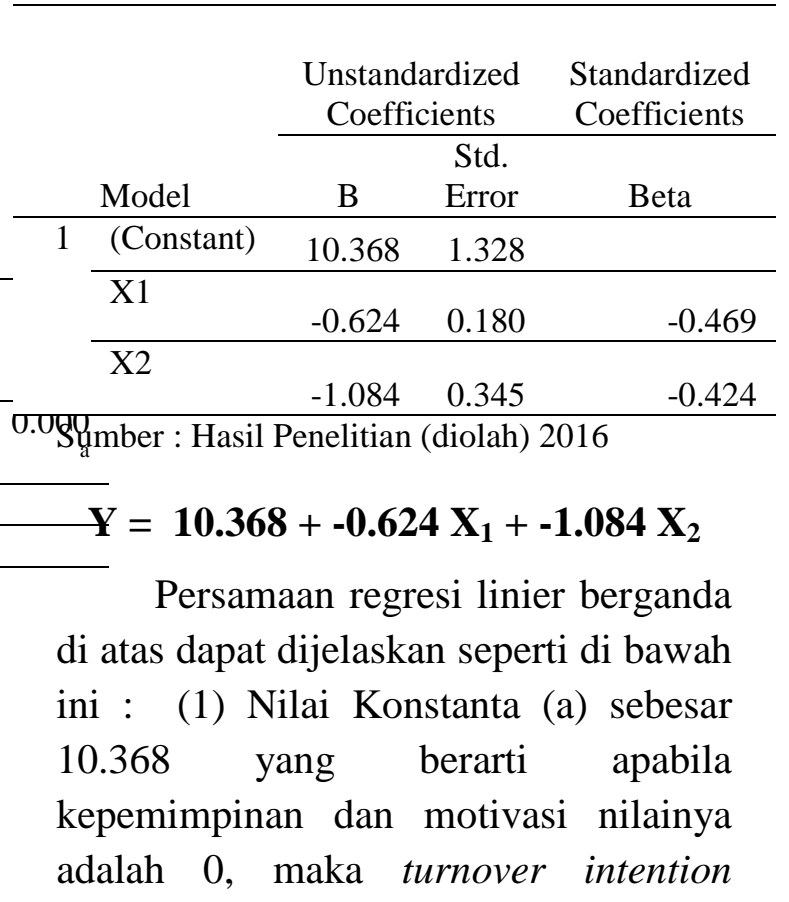


nilainya adalah 10.368 satuan. (2) Nilai koefisien regresi variabel kepemimpinan sebesar -0.624 yang berarti jika variabel indenpenden lainnya tetap dan kepemimpinan mengalami kenaikan 1 satuan, maka akan menyebabkan turnover intention penurunan sebesar 0.624 satuan. keofisien bernilai negatif artinya terjadi hubungan negatif, kepemimpinan yang tinggi akan menurunkan turnover intention. (3) Nilai koefisien regresi variabel motivasi sebesar -1.084 yang berarti jika variabel indenpenden lainnya tetap dan motivasi mengalami kenaikan 1 satuan, maka akan menyebabkan turnover intention penurunan sebesar 1.084 satuan. keofisien bernilai negatif artinya terjadi hubungan negatif, motivasi yang tinggi akan menurunkan turnover intention.

\section{Uji Hipotesis}

\section{Uji t (Uji Parsial)}

\section{Tabel 6. Hasil Uji t}

\begin{tabular}{ccccl}
\hline Model & T & Sig. & Keterangan \\
\hline 1 & Constant) & 7.808 & 0.000 & \\
\cline { 2 - 5 } X1 & -3.471 & 0.002 & Signifikan \\
\hline $\mathrm{X} 2$ & -3.139 & 0.004 & Signifikan \\
\hline
\end{tabular}

Sumber : Hasil Penelitian (diolah) 2016

Berdasarkan tabel diatas, uji parsial dari hasil penelitian ini adalah sebagai berikut : (1). Hasil pengujian menunjukkan bahwa nilai $\mathrm{t}$ hitung untuk variabel kepemimpinan -3.471 lebih besar dari $\mathrm{t}$ tabel 1.69389 atau nilai signifikan 0.002 lebih kecil dari alpha 0.05. maka H0 ditolak dan H1 diterima yakni kepemimpinan berpengaruh secara negatif terhadap turnover intention (2) Hasil pengujian menunjukkan bahwa nilai $t$ hitung untuk variabel motivasi -3.139 lebih besar dari $\mathrm{t}_{\text {tabel }} 1.69389$ atau nilai signifikan 0.004 lebih kecil dari alpha 0.05. maka hipotesis dapat diterima, arah koefisien regresi negatif berati motivasi memiliki pengaruh secara negatif yang signifikan terhadap turnover intention, dengan kata lain semakin bagus motivasi akan mengurangkan turnover intention dan juga sebaliknya.

Pengaruh Kepemimpinan terhadap Turnover Intention

Dari hasil analisis secara deskriptif, menunjukkan bahwa kepemimpinan merupakan faktor yang dianggap baik oleh responden yang mana mempengaruhi tingkat turnover intention. Hal ini sejalan dengan hasil analisis regresi dan pengujian secara parsial (uji t) terhadap variabel kepemimpinan yang menunjukkan bahwa variabel kepemimpinan memiliki nilai yang negatif dan signifikan, artinya secara parsial dapat dinyatakan variabel kepemimpinan berpengaruh nyata terhadap tingkat turnover intention.

Yang berarti secara parsial dapat dinyatakan variabel kepemimpinan berpengaruh nyata terhadap tingkat turnover intention. hal ini dikarenakan karakteristik pendidikan dari responden dimana semua karyawan telah telah menjalani tahap pendidikan yang ditetapkan berdasarkan tingkat perkembangan peserta didik yang harus dilakasanakan minimal 9 tahun. dengan kata lain semua karyawan memiliki pengetahuan untuk membandingkan apakah pertukaran imbalan yang disepakati antara atasan dan bawahan seimbang.

Dari hasil penelitian yang dilakukan oleh peneliti terdahulu yang 
dilakukan Caesary (2013) bahwa kepemimpinan memiliki pengaruh yang signifikan terhadap turnover intention, berarti dari penelitian sebelumnya dan penelitian yang dilakukan saat ini terdapat kesamaan yaitu dari hasil pengujian sebelumnya dan penelitian yang dilakukan sekarang terdapat pengaruh yang kuat pada variabel tersebut.

\section{Pengaruh Motivasi terhadap Turnover Intention}

Dari hasil analisis secara deskriptif, menunjukkan bahwa motivasi merupakan faktor yang dianggap baik oleh responden yang mana mempengaruhi tingkat turnover intention. hal ini sejalan dengan hasil analisis regresi dan pengujian secara parsial (uji t) terhadap variabel motivasi yang menunjukkan bahwa variabel motivasi memiliki nilai yang negatif dan signifikan.

Yang berarti secara parsial dapat dinyatakan variabel motivasi berpengaruh nyata terhadap tingkat turnover intention. Dimana semakin baik motivasinya maka akan meminimalkan terjadinya turnover intention sebaliknya, semakin buruk motivasinya maka akan terjadi peningkatan turnover intention. hal ini dikarenakan karakteristik status responden mayoritas telah menikah, dimana responden dengan status menikah memiliki kedisiplinan kerja yang besar dalam bekerja hal ini dikarenakan karyawan dengan status menikah memiliki tanggungan keluarga dan lebih membutuhkan pekerjaan yang dimilikinya sehingga mereka lebih giat dalam bekerja. Hasil ini didukung oleh Sukron (2014) dimana penelitiannya menunjukkan bahwa motivasi berpengaruh negatif terhadap turnover intention.

\section{PENUTUP}

Kesimpulan

Berdasarkan hasil penelitian dan pembahasan serta uraian bab-bab sebelumnya, maka dapat disimpulkan sebagai berikut: (1). kepemimpinan memiliki pengaruh yang signifikan terhadap turnover intention karyawan di Panca Sumber Diesel Pekanbaru. Dalam penelitian ini kepemimpinan memiliki pengaruh yang negatif sehingga apabila variabel kepemimpinan semakin kuat maka turnover intention di Panca Sumber Diesel juga akan semakin menurun. (2). Motivasi memiliki pengaruh yang signifikan terhadap turnover intention karyawan di Panca Sumber Diesel Pekanbaru. Dalam penelitian ini motivasi memiliki pengaruh yang negatif sehingga apabila motivasi semakin kuat akan menurunkan turnover intention.

\section{Saran}

Berdasarkan kesimpulan yang diperoleh dalam penelitian ini, maka diajukan saran-saran sebagai pelengkap terhadap hasil penelitian yang dapat diberikan sebagai berikut : (1). Kepemimpinan yang diterapkan oleh perusahaan memiliki tanggapan yang baik dari respondennya, dengan adanya pengawasan yang cukup ketat dari pimpinan dan kesepakatan yang diadakan oleh atasan dan bawahan seperti apabila karyawan memiliki performa yang bagus maka karyawan akan mendapatkan imbalan dari atasan. kepemimpinan yang diterapkan ini dapat dipertahankan karenan mempengaruhi turnover intention. (2). Motivasi yang diberikan oleh perusahaan hendaknya perlu ditingkatkan lagi oleh perusahaan seperti mengetahui apa harapan dari karyawan yang paling dibutuhkan saat berada di perusahaan sehingga akan meminimalkan terjadinya turnover 
intention.(3) Penelitian ini dibatasi pada variabel kepemimpinan dan motivasi sehingga perlu dilakukan penelitianpenelitian lanjutan yang mempengaruhi turnover intention seperti lingkungan kerja, kompensasi, mengingat ada faktor lain yang masih mempengaruhi turnover intention sebesar $48.8 \%$.

\section{DAFTAR RUJUKAN}

Caesary, (2013). Pengaruh Gaya Kepemimpinan

Transformasional Terhadap Keinginan Keluar Karyawan Pada Agent Outbound Call PT. Infomedia Nusantara. Journal of Economic Education.

Hedrajrahcman \& Husnan Suad, (2011). Manajemen Personalia. Yogyakarta: BPFE UGM.

Hasibuan, Melayu. (2012). Manajemen Sumber Daya Manusia”. Jakarta : PT. Bumi Aksara.

Mathis R.L dan Jackson J.H, (2006), Manajemen Sumber Daya Manusia, Diterjemahkan oleh Jimmy Sadeli dan Bayu Prawira Hie, Edisi kelima, Salemba Empat, Jakarta.

Mangkunegara, A.Anwar Prabu, (2007). Manajemen Sumber daya Manusia perusahaan. Bandung : PT.Remaja Rosdakarya.

Robbins, S.P. (2006). Mendefinisikan Turnover Sebagai Pemberhentian. Jakarta.

Robbins, Stephen P. (2006). Prilaku Organisasi. Ahli bahasa: Handayana Pujaatmaka. Jakarta, Prenhallindo

Rivai, Veithzal. (2009). Manajemen Sumber Daya Manusia Untuk Perusahaan Dari Teori ke Praktik. Jakarta: Raja Grafindo Persada.
Rivai, V. (2009). Kepemimpinan dan Perilaku Organisasi. Jakarta: Raja Grafindo Persada.

Rodly, I. A., (2012). Turnover Karyawan Kajian Literatur, Buku Online.

Samsudin, (2010). Manajemen Sumber Daya Manusia. Bandung: Pustaka Setia.

Sukron, Roni Ardiyansyah, (2014). Pengaruh motivasi terhadap turnover intention. Artikel Ilmiah mahasiswa 